\title{
CORRECTION
}

Open Access

\section{Correction to: Discordant serum lipid parameters}

\author{
Ozge Kurmus ${ }^{*}$, Turgay Aslan, Murat Eren and Kursat Akbuga \\ Correction to: Lipids Health Dis 20, 10 (2021) \\ https://doi.org/10.1186/s12944-021-01445-5
}

Following publication of the original article [1], it was reported that the response by the authors of "Apolipoprotein $\mathrm{B}$ and non-high-density lipoprotein cholesterol reveal a high atherogenicity in individuals with type 2 diabetes and controlled low-density lipoproteincholesterol" [2] was missing in the main text. This response has been added and the original article has been corrected.

Published online: 25 May 2021

\footnotetext{
References

1. Kurmus O, Aslan T, Eren M, et al. Discordant serum lipid parameters. Lipids Health Dis. 2021;20:10 https://doi.org/10.1186/s12944-021-01445-5.

2. Fonseca L, Paredes S, Ramos H, et al. Apolipoprotein B and non-highdensity lipoprotein cholesterol reveal a high atherogenicity in individuals with type 2 diabetes and controlled low-density lipoprotein-cholesterol. Lipids Health Dis. 2020;19:127 https://doi.org/10.1186/s12944-020-01292-w.
}

The original article can be found online at https://doi.org/10.1186/s12944 021-01445-5.

*Correspondence: ozge_kurmus@yahoo.com

Department of Cardiology, Faculty of Medicine, Ufuk University,

MevlanaBulvari (Konya yolu), No: 86-88, Balgat, Ankara, Turkey

(C) The Author(s). 2021 Open Access This article is licensed under a Creative Commons Attribution 4.0 International License, which permits use, sharing, adaptation, distribution and reproduction in any medium or format, as long as you give appropriate credit to the original author(s) and the source, provide a link to the Creative Commons licence, and indicate if changes were made. The images or other third party material in this article are included in the article's Creative Commons licence, unless indicated otherwise in a credit line to the material. If material is not included in the article's Creative Commons licence and your intended use is not permitted by statutory regulation or exceeds the permitted use, you will need to obtain permission directly from the copyright holder. To view a copy of this licence, visit http://creativecommons.org/licenses/by/4.0/. The Creative Commons Public Domain Dedication waiver (http://creativecommons.org/publicdomain/zero/1.0/) applies to the data made available in this article, unless otherwise stated in a credit line to the data. 